\title{
Failure That Matters: Two Abortive Agreements and the Dynamics of Orthodox Jewish Politics on the Eve of World War II
}

\author{
DANIEL MAHLA \\ Ludwig Maximilian University of Munich, Munich, Germany \\ E-mail:daniel.mahla@lrz.uni-muenchen.de
}

\begin{abstract}
Agudat Yisrael and the religious Zionist movement (Mizrachi) were the two largest and most influential political organizations of Orthodox Jewry during the first half of the twentieth century. Competing for the support of observant Jews, the two movements were enmeshed in bitter ideological and political struggles. Nevertheless, due to the dire situation of European and Palestine Jewries their political representatives met during the late 1930s in Paris and London in order to negotiate possible avenues of cooperation. While these endeavors were unprecedented in the history of the two movements, they eventually failed. Due to their failure, earlier scholarship has dismissed these efforts as a "lost opportunity" for Orthodox Judaism and blamed Agudists for their unwillingness to overcome long-standing rivalries and ideological reservations. This article, in contrast, perceives the negotiations of 1938-1939 as an important window into intra-Orthodox dynamics during the first half of the twentieth century. Rather than stressing the difficulties of overcoming ideological barriers and the failures of non-Zionist Orthodoxy to adapt to the challenges of the modern age, the article argues that it was a careful weighing of political gains and risks on both sides that dominated the negotiations and determined their outcome. The insights gained from this close analysis of intra-Orthodox relations are of significance beyond the question of party politics, as the two rivals were not only influential political movements, but ultimately came to shape the social, cultural, and political realities of traditionalist Jewry in the State of Israel during its early years and well beyond.
\end{abstract}

Keywords Orthodox Judaism · Modern Jewish Politics · East Central Europe · Palestine · Israel $\cdot$ Zionism $\cdot$ Mizrachi $\cdot$ Agudat Yisrael

On April 4, 1938, a small group of Orthodox Jews from Europe and Palestine gathered at the Ambassador Hotel in the 9th arrondissement of Paris, a large and luxurious accommodation that regularly hosted affluent tourists from around the world. For the eight bearded men with traditional Jewish yarmulkes on their heads, the venue had the benefit of proximity to the Great Synagogue of Paris, where they could say their daily prayers. In contrast to many of the hotel's other guests, the men assembled were not in Paris to see the sights. Jacob Rosenheim, Moshe Blau, Yitzhak Breuer, Shlomo Ehrman, Meir Berlin, Ze'ev Gold, Shmuel Brodt, and Zalman Shragai were representatives of the two largest and most influential Orthodox movements, the non-Zionist Agudat Yisrael (Agudah) and the religious Zionist Mizrachi, and 
their gathering constituted a minor sensation within the world of traditional Jewry. Since the early years of these two movements, their spokesmen had engaged in harsh and seemingly relentless ideological and political competition. The assembly in Paris was the first meeting of their top-ranking leaders in a long time.

Following two days of intense negotiation, the men reached a noteworthy agreement to cooperate on several urgent issues: improving the economic situation of Orthodox educational institutions in East Central Europe, countering advancing secularization, strengthening religious settlements in Palestine, and working to safeguard religious tenets and institutions within the emerging Jewish political frameworks under the British Mandate. The scale of the meeting and the consent of leading politicians to participate in these joint campaigns were unprecedented in the history of the two movements, and the results of the Paris summit were lauded as a major breakthrough on the way to mutual recognition and rapprochement. Many Orthodox activists deemed the Paris accords a major success for religious Jewry and hoped that they would inspire further-reaching arrangements in the future. ${ }^{1}$

This momentous 1938 meeting between Orthodox Jewish politicians took place against the backdrop of severe geopolitical change. Throughout the 1930s, Jews across East and Central Europe had been under strong economic pressure and were politically and socially ostracized. Anti-Jewish legislation and violence shaped not only the lives of German Jews under the rising Nazi regime, but also afflicted Europe's largest Jewish community in the neighboring Polish state. In Palestine, too, living conditions had worsened considerably since the outbreak of the Arab Revolt in 1936. Yet despite the seeming success of the Paris summit and the increasingly grave situation of European Jewry, particularly in light of world events that unfolded over the months ahead, the great hopes that activists and politicians had pinned on the meeting and its outcome were soon shattered. The Mizrachi presidium quickly ratified the agreement, and several internationally renowned rabbinic authorities expressed their willingness to back such cooperation. Agudah's rabbinic council, however, offered resistance. Following months of diplomatic efforts, in February 1939 political leaders from both sides met again, this time in London, to draft an alternative agreement with a more limited focus that pertained mostly to joint fundraising activities. There was, however,

\footnotetext{
${ }^{1}$ For a summary of the meeting and its results, see Protokol mi-ha-Yeshivah ha-Meshutefet bein ha-Agudah ve-ha-Mizrahi be-Yom 4.4.1938 be-Malon Ambasador be-Paris, in Archives for the Research of Religious Zionism (henceforth: ARRZ) 001-495. For details regarding the negotiation process, see "Din ve-Heshbon ha-Merkaz ha-'Olami shel ha-Mizrahi le-Ve'idah ha-'Olamit ha-15' be-Genevah,' August 6-13, 1939, 80 in ARRZ 006-36. The methodological challenges of these sources are discussed in the body of the article.
} 
strong opposition, this time mainly on the side of Mizrachi, and this endeavor ultimately failed, as well.

Scholarship to date has largely cast the failure of these accords as the product of disunity among Agudah leaders and their unwillingness to overcome long-standing rivalries and ideological reservations. Mizrachists, according to this narrative, repeatedly attempted to initiate cooperation but their overtures were rejected time and again by their non-Zionist counterparts, who were slow to adapt to changing geopolitical and social realities. "The Paris conference at the Ambassador Hotel," wrote Monty Penkower in a pioneering article on Agudah-Mizrachi negotiations, "represented a lost opportunity to forge a modus vivendi for the Orthodox cause in Israel and in the Diaspora. In the time of their people's unprecedented anguish, Agudah finally could not transcend longstanding differences with Mizrachi, riveted in the bitter clash of ideology and personality, a Kulturkampf for Jewry's future soul."2 Commenting on the same negotiations in his work on Agudat Yisrael and the Zionist movement, Yosef Fund took a similar line when faulting Agudists for their "difficulties to get attuned to the idea of working together with an ideological rival." 3 These positions fit with a broad tendency among researchers to accuse non-Zionist Orthodoxy of intellectual stagnation and political passivity vis-à-vis the radical challenges that Jewish societies were facing in the late nineteenth and early twentieth centuries. By their telling, religious Zionists were the ones who recognized the signs of the times and displayed "a boldness and sense of historic responsibility that Orthodoxy was trying to evade." 4

To be sure, the inability of Orthodox leaders to cooperate during such difficult years is disconcerting even without taking into consideration the outbreak of World War II and the destruction of European Jewry in the Holocaust

\footnotetext{
${ }^{2}$ Monty Penkower, "A Lost Opportunity: Pre-World War II Efforts Towards Mizrachi-Agudas Israel Cooperation," Journal of Israeli History 17, no. 2 (1996): 246.

${ }^{3}$ Fund does not see the negotiations "as a complete failure." In his opinion, they constituted Agudah's first step toward political convergence with Mizrachi. Yosef Fund, Perud o Hishtatfut: Agudat Yisra'el mul ha-Ziyonut u-Medinat Yisra'el (Jerusalem, 1999), 201f. In a similar vein, Zev Bauer points to the difficulties of Agudah in adjusting its ideology to changing geopolitical frameworks. He also lists the power struggles between different national Agudah branches as reason for the failure of the agreements. See his "Ha-Yahasim ha-Penimiim be-Yahadut ha-Datit likrat Hakamat Medinat Yisra'el u-ve-'Ikvoteiha, ve-Khinun he-Hasit ha-Datit ha-Me'uhedet" (PhD diss., The Hebrew University of Jerusalem, 2011, 104). All translations are the author's, unless otherwise indicated.

${ }^{4}$ For an important critique of this depiction of traditionalist Jewry, see Glenn Dynner, "Jewish Traditionalism in Eastern Europe: The Historiographical Gadfly," Polin 29 (2017): 285-99. Among others, he cites the lines quoted above, which Ehud Luz phrased in his work on religion and nationalism in the early Zionist movement. See ibid., 294; Ehud Luz, Parallels Meet: Religion and Nationalism in the Early Zionist Movement (1882-1904), trans. Lenn J. Schramm (Philadelphia, 1988), 226.
} 
only shortly thereafter. But focusing on the causes and culprits of failure obscures other important aspects of these negotiations. Religious Zionists and Agudists were not only ideological opponents but also competed for social and political power and influence in Jewish communities throughout Europe and Palestine. In the 1920s and 1930s, most contact between the two movements took place on the level of mutual attacks in the parties' media, with their representatives seldom engaging in face-to-face discussion. ${ }^{5}$ The negotiations of 1938 and 1939 constitute a unique window into Agudah-Mizrachi interaction, and close examination of the way they unfolded uncovers an intricate web of mutual relations and differing political interests, thus painting a more nuanced picture of intra-Orthodox dynamics. Rather than focusing on the difficulties the movements faced when attempting to overcome ideological barriers, and the failures of non-Zionist Orthodoxy to adapt to the challenges of the modern era, this article argues that a careful weighing of political gains and risks on both sides dominated the negotiations and determined their outcome. The insights gained from this close analysis of intra-Orthodox relations are of significance beyond the question of party politics, as the two rivals were not only influential political movements, but ultimately came to shape the social, cultural, and political realities of traditionalist Jewry in the State of Israel during its early years and well beyond. After briefly reviewing the emergence of the two movements, I give a detailed reconstruction of the negotiation process and then examine the dynamics leading to both the original agreements and their eventual collapse.

\section{Orthodox Relations during the First Decades of the Twentieth Century}

Both Agudat Yisrael and Mizrachi emerged during the first decades of the twentieth century. In Vilna, a hotspot of Jewish political activism in the Russian Empire, several activists founded the religious Zionist party Mizrachi

\footnotetext{
${ }^{5}$ One of the few exceptions was the debate concerning a joint Orthodox World Congress in 1933-1934, but no meeting of high-ranking representatives comparable to that in Paris took place during this period. Local Polish leaders met within Jewish communal structures $(k e-$ hillot) on a regular basis. For details of the debates of 1933-1934, as well as those within the Polish kehillot, see Daniel Mahla, Orthodox Judaism and the Politics of Religion: From Prewar Europe to the State of Israel (New York, 2020). The relative openness to cooperation of the workers' parties of the two movements is also worthy of note. Poalei Agudat Yisrael (PAY) and Ha-Poel Ha-Mizrachi reached an agreement to establish a joint trade union in 1936, which was ultimately rejected by Agudah's rabbinic council. For details, see Yosef Avneri, “'Heskem she-lo Butza': Te'ud ha-Masa u-Matan bein ha-Po'el ha-Mizrahi le-Po'alei Agudat Yisra'el be-Shenot ha-Sheloshim al Hakamat Tenu'at Po'alim meshutefet," in Bi-Shvilei ha-Tehiyah: Mehkarim ba-Tziyonut ha-Datit, vol. 2, ed. Mordekhai Eliav (Ramat Gan, 1987), 167-99; Bauer, Ha-Yahasim ha-Penimiim, 107-34.
} 
in 1902. A product of conflicts within the Zionist movement concerning engagement with modern culture, Mizrachi quickly became an important political venue for observant activists. ${ }^{6}$ Ten years later, rabbinic authorities and lay leaders from Central Europe and the Russian Empire gathered in Kattowitz in the German Empire to launch Agudat Yisrael. Agudah aimed to unite traditionalist elites from Europe and Palestine and to provide an alternative to the political activism of socialist and nationalist parties. ${ }^{7}$

Within several years of their founding, both Mizrachi and Agudat Yisrael had established multiple branches throughout Europe and Palestine. Despite the plethora of stakeholders and institutions appealing to traditionalist Jewry during this period, the two organizations quickly proved themselves influential players. ${ }^{8}$ Competing directly for the support of observant Jews, the two became enmeshed in bitter ideological and political struggles. Their adherents fought over rabbinic posts, power in local Jewish communities, and political representation in different countries and on the international level. While neither group was able to garner the majority of Jewish votes in such crucial arenas as the Second Polish Republic, Agudah enjoyed far greater support among the traditionalist masses. What is more, the movement's Council of Torah Sages included some of the most important religious authorities of the time. In contrast, Mizrachi could boast far less electoral success and very little rabbinic support. ${ }^{9}$ This, however, did not render the organization insignificant. The strength of religious Zionism lay in the social and political activism of its adherents and leaders, and in Mizrachi's organizational advantages as part of the Zionist Organization (ZO). Especially among the youth, religious Zionism constituted a significant challenge to traditionalist understanding of Jewish social organization. ${ }^{10}$

\footnotetext{
${ }^{6}$ For early struggles in the Zionist movement over matters of culture and the founding of Mizrachi, see Luz, Parallels Meet.

${ }^{7}$ Regarding the founding of Agudat Yisrael, see Gershon C. Bacon, The Politics of Tradition: Agudat Yisrael in Poland, 1916-1939 (Jerusalem, 1996), 26-37; and Alan Mittleman, The Politics of Torah: The Jewish Political Tradition and the Founding of Agudat Israel (Albany, 1996).

${ }^{8}$ It is important to note that a great variety of Orthodox institutions existed long before these two movements were founded and continued to flourish and compete with Agudah and Mizrachi, especially on the local and regional levels. For the political involvement of Orthodox Jews as early as the mid-nineteenth century, see, for example, Rachel Manekin, The Jews of Galicia and the Austrian Constitution: The Beginning of Modern Jewish Politics [in Hebrew] (Jerusalem, 2015).

${ }^{9}$ Regarding the electoral success of Jewish parties and the Polish chapters of the two Orthodox rivals, see Bacon, The Politics of Tradition, 207-21; Ezra Mendelsohn, On Modern Jewish Politics (New York, 1993) 65-73; and Asaf Kaniel, Aspirations and Achievements: Mizrachi in Interwar Poland [in Hebrew] (Ramat Gan, 2011), 32-49.

${ }^{10}$ Even Polish authorities, who monitored the political activities of the states' ethnic and religious minorities during the interwar period, identified the high fluctuation of adherents and
} 
Agudists opposed the aims of the $\mathrm{ZO}$ and were reluctant to work with its institutions. Nevertheless, in the aftermath of World War I, the movement established a local office in Palestine and became increasingly involved in the affairs of the local Jewish communities. As the situation of East Central European Jewry grew more and more dire during the late 1920s and 1930s, Palestine became an increasingly important destination for emigration, and Agudah's presence and activities in this arena expanded accordingly. In this context, Agudists came in ever-closer contact with the $\mathrm{ZO}$, and the two organizations began to discuss possible areas of cooperation, despite their mutual enmity. ${ }^{11}$ The gradual rapprochement between Agudah and the Zionist institutions also impacted intra-Orthodox dynamics and compelled Orthodox leaders to reconsider their reciprocal relations. While both Agudah and Mizrachi leaders were concerned about the advance of secularism and worked to safeguard Orthodox lifestyles and frameworks, they were, at the same time, bitter political adversaries. Agudah's gradual rapprochement with Zionist institutions did not, in fact, lead to a convergence of the approaches and interests of the Orthodox movements, but actually intensified mutual competition for power and influence. ${ }^{12}$

With these developments in mind, we can now analyze the negotiations in Paris and in London during the late 1930s.

\section{Paris and London: Two Agreements, Few Results}

The momentous meeting of Mizrachi and Agudah leaders in Paris was initiated by religious Zionists from Europe, Palestine, and the United States, who convened in July and August 1937 in Zurich for the fourteenth world congress of their movement. Congress participants mandated Mizrachi's political executive to explore possibilities for Orthodox cooperation. ${ }^{13}$ Mizrachists had promoted cooperation between the two movements in the

\footnotetext{
Agudah's difficulty in preventing its youth from defecting to the youth groups of Mizrachi and other parties. See, for example, Sprawozdanie (Jan.-Mar. 1935), in Archiwum Akt Nowych MSW IV/98.

${ }^{11}$ Regarding the activities of Agudah in Palestine and inner tensions, see Menachem Friedman, Hevrah va-Dat: Ha-'Ortodoksyah ha-lo-Ziyonit be-Erez-Yisra'el, 5678-5696 (Jerusalem, 1977). For negotiations with the ZO, see Fund, Perud o Hishtatfut, 164-77.

${ }^{12}$ For a detailed analysis of tripartite relations between the two Orthodox movements and the ZO during the 1920s and 1930s, see Daniel Mahla, "No Trinity: The Tripartite Relations between Agudat Yisrael, the Mizrahi Movement and the Zionist Organization," Journal of Israeli History 34, no. 2 (2015): 117-40.

${ }^{13}$ Hahlatot ha-Ve 'idah ha-Olamit ha-14' shel ha-Mizrachi be-Zirikh, July 28-August 3, 1937, in ARRZ 006-36.
} 
past, but this time things seemed more promising. In 1935, Mizrachists had entered a historical alliance with the Labor Zionist movement, a decision that ended a period of harsh inner-party struggles concerning the ideological and organizational orientation of the party. At the same time, the situation of religious Jewry in Eastern Europe and Palestine further deteriorated, and Orthodox leaders from both parties were alarmed when, in the context of British efforts to stabilize the tumultuous situation in Palestine, the foundation of a Jewish state seemed suddenly within reach. Against this backdrop, attempts to work together to strengthen religious institutions and life in Europe, as well as in the Jewish settlements in Palestine, seemed to gain more traction. Taking up the delegates' mandate, the secretary of the international Mizrachi, Meir Berlin, approached the president of Agudat Yisrael, Jacob Rosenheim, shortly after the congress and proposed a meeting between highranking politicians of both movements. ${ }^{14}$ Rosenheim, who had himself been at the forefront of previous attempts to foster intra-Orthodox cooperation, welcomed the initiative and delivered Berlin's blessings to the third Agudah World Congress in Marienbad (today's Mariánské Lázně) just two weeks later. The participants of this meeting applauded Berlin's overture and approved Mizrachi's request. ${ }^{15}$ Their spontaneous consent seemed to indicate a new willingness for rapprochement. Agudah leaders contended with strong criticism during these years for not having done enough for religious settlements in Palestine, and Mizrachi's initiative may have been a welcome opportunity to demonstrate their awareness of just how critical this issue was to the Jewish masses in Europe. Subsequent follow-up strengthened the impression that both sides were indeed interested in rapprochement. Old resentments and mistrust resurfaced in debates over an appropriate meeting-place, but after some to and fro, both sides eventually agreed to convene on April 4 and 5, 1938, in the Ambassador Hotel in Paris.

In Paris itself, the atmosphere among representatives was friendly. Over the course of two intense days, participants considered how they might work together for the good of Orthodox Jews in both Europe and Palestine. The protocols of these discussions, preserved in the Archives for the Research

\footnotetext{
${ }^{14}$ Meir Berlin to Jacob Rosenheim, August 17, 1937, reprinted in Din ve-Heshbon ha-Merkaz ha-'Olami shel ha-Mizrahi le-Ve'idah ha-'Olamit ha-15' be-Genevah, 6.8.-13.8.1939, 63f, in ibid., 006-36. Meir Berlin (1880-1949), who later changed his name to Bar-Ilan, came from a distinguished rabbinic family in Volozhin (today's Belarus). He was active in Mizrachi from the first days of the movement. Berlin spent World War I in the U.S. and immigrated to Palestine in 1926. He held numerous offices in Mizrachi and the Zionist Organization. Jacob Rosenheim (1870-1965) from Frankfurt wrote extensively on political topics and published the Orthodox newspaper Der Israelit. He was among the most important founding figures of Agudat Yisrael, and later became the movement's president.

${ }^{15}$ As Jacob Rosenheim reported to Meir Berlin in his answer, see ibid., 64.
} 
of Religious Zionism at Bar Ilan University, suggest that both sides demonstrated empathy and goodwill, but that disagreement and friction remained. Mizrachi leaders emphasized that their meeting would resonate positively with the Jewish masses. Agudists, by contrast, tried to trim back expectations, and stressed the confidential and limited character of the meeting. ${ }^{16}$ The reported wariness of Agudah's politicians reflected the movement's modus operandi: its leaders generally preferred to act behind the scenes. Mizrachi, on the other hand, tended to advertise their political activities widely in order to attract adherents. Yet, in this context, it is worth noting that the reconstruction of the Paris meeting, as well as of intra-Orthodox dynamics more generally, both relied heavily on Mizrachi sources, who created and preserved many more archival materials than their Agudah counterparts. Historians would be wise to take this imbalance into consideration, as it implies that our impression of events is filtered largely through a religious Zionist lens. ${ }^{17}$

Notwithstanding such differences and despite a number of unresolved issues, the participants eventually reached agreement on several issues: both sides approved a meeting in Vilna of the rashei yeshivah, or deans of Eastern European yeshivot, to discuss ways to improve the economic situation of those institutions. In addition, leaders of both parties declared their intention to launch a joint campaign to foster the observance of Jewish law among the masses and to combat processes of secularization; Mizrachi and Agudah representatives agreed to coordinate their efforts to ensure religious rights in the anticipated Jewish state; the eight participants in the Paris summit announced that their movements would henceforth insist on joint appearances at meetings with the $\mathrm{ZO}$ and at hearings before the British authorities regarding their demands of a future state; and, finally, they arranged to work together to support religious settlements in Palestine. The leaders committed to organizing joint committees to work out the details of these agreements and undertook that both sides would submit the accords to their highest party councils for ratification. ${ }^{18}$

\footnotetext{
${ }^{16}$ Protokol mi-ha-Yeshivah ha-Meshutefet bein ha-Agudah ve-ha-Mizrahi be-Yom 4.4.1938 be-Malon Ambasador be-Paris, in ibid., 001-495. The protocol is reprinted together with additional documents in "Nisayon she-lo ala Yafe," in Sefer ha-Ziyonut ha-Datit: Iyunim, Ma'amarim, Reshimot, Te 'udot, ed. Yitzhak Rapha'el and Zalman Shragai (Jerusalem, 1977), 517-29.

${ }^{17}$ This imbalance is exacerbated by the fact that the two most important Mizrachi archives are freely accessible, whereas access to much of the Agudah material, currently located in party headquarters in Jerusalem, is granted very selectively. This restricted access is only partially counterbalanced by the archives of the movement's US branch in New York City, which are open to the public.

${ }^{18}$ Protokol mi-ha-Yeshivah ha-Meshutefet bein ha-Agudah ve-ha-Mizrachi be-Yom 4.4 .1938 be-Malon Ambasador be-Paris, in ARRZ. 001-495.
} 
In the aftermath of the Paris conference, Mizrachi and Agudah representatives informed their adherents of the meeting's resolutions and announced them in their respective party presses. Mizrachi newspapers struck an enthusiastic tone, celebrating the agreement as a great success for Orthodox Jewry, in general, and for their movement, in particular. ${ }^{19}$ "Could anyone be so blind," Meir Berlin asked rhetorically in an interview with the Polish Mizrachi organ, Di Yudishe Shtime, "not to see the great success that national-religious Jewry attained through this agreement?"20 Agudist press organs also reported on the meeting, yet their coverage was very different in spirit. Careful not to stir premature hopes, Agudah newspapers informed their readers of the developments in a mostly matter-of-fact tone and made sure to stress that the accords still awaited the ratification of their movement's rabbinic council. ${ }^{21}$ One of the first articles to appear in Agudah's organ in Palestine, Kol Yisrael, deemed it necessary to notify its readers that the party leadership wished to correct some inaccurate impressions conveyed by "non-Agudist" (read, Mizrachi) newspapers. The agreement most likely to be implemented, its author held, was a united religious front, if and when a Jewish state was established. ${ }^{22}$

In the meantime, the diplomatic process stagnated. As soon as details of the agreement became known, the deans of the great Eastern European yeshivot publicly rejected any cooperation for the benefit of their institutions-to avoid, they claimed, the interference of political parties. Mizrachi's presidium ratified the agreement quickly, but it soon became clear that it would be far more difficult to obtain the official approval of Agudah's Council of Torah Sages. ${ }^{23}$ The renowned rabbi of Vilna, Chaim Ozer Grodzenski, himself a member of the council, supported the agreement and

\footnotetext{
${ }^{19}$ See, for example, the Polish Di Yudishe Shtime, April 15, 1938, 2; April 29, 1938, 2f; May 6, 1938, 2; May 13, 1938, 2. Ha-Zofeh in Palestine reported similarly: Ha-Zofeh, April 7, 1938, 1; April 13, 1938, 1; May 5, 1938, 2f; May 5, 1938, 3; April 21, 1938, 1.

${ }^{20}$ Di Yudishe Shtime, May 20, 1938, 5.

${ }^{21}$ The only exception to this was the media representing Agudah's labor wing, which hailed the conference as a great victory for observant workers (Ha-Yesod, April 10, 1938, 3). The article was by one of the leaders of the Agudah's workers' movement, PAY, Benjamin Mintz. Though hailing the agreement as an important beginning, he demanded that leaders of both sides take further steps to deepen cooperation. He also strongly criticized the Agudah leadership. The Polish Mizrachi newspaper Di Yudishe Shtime reprinted his article about a month later in Yiddish (Di Yudishe Shtime, May 6, 1938, 5). For the frictions and disagreements between the Agudah mother movement and its workers' wing, see Bacon, The Politics of Tradition, 101-15.

${ }^{22}$ Kol Yisrael, April 28, 1938, 4; May 19, 1938, 3. See also the Polish newspaper Dos Yudishe Togblat, April 7, 1938, 2; April 20, 1938, 2, and the German Der Israelit, April 7, 1938, 2.

${ }^{23}$ World Mizrachi Office to Executive of Agudat Yisrael, April 26, 1938, in Archives of Religious Zionism (henceforth: ARZ), MO143.
} 
went to great lengths to convince his colleagues. ${ }^{24}$ Rosenheim remained in close contact with Mizrachi leaders and repeatedly assured them that he and Grodzenski were working hard to ensure that the agreed cooperation would move forward. His tone, however, was increasingly pessimistic. Polish Agudists, he informed his Mizrachi partners in May, had urged their leadership to avoid any steps conveying the impression that the two movements would enter a political federation. All sides had to make it perfectly clear that this was nothing but a onetime cooperation. Echoing an earlier criticism voiced by his Polish colleague, Isaac Meir Levin, ${ }^{25}$ Rosenheim bemoaned Mizrachi's enthusiastic media coverage.

"The publication of the Paris agreement," he wrote, "has stirred hopes in a completely unnecessary manner; hopes that were objectively not justified. [...] You might recall," he continued, "that I have been opposed to their publication from the beginning, and I feel sorry that I yielded in this point to my own friends, as well as to yours." 26

In the following weeks, the process seemed to stagnate. Months later, Mizrachi leaders still bemoaned the lack of a decision by Agudah's rabbinic council. As it turned out, although several council members supported the agreement, it was impossible to attain approval from everyone. ${ }^{27}$ In an attempt to break the deadlock, some political representatives started to explore alternative options. In November 1938, the leader of Mizrachi's workers movement in Palestine, Zalman Shragai, returned to Paris to meet with Solomon Ehrmann from Agudat Yisrael. ${ }^{28}$ Together, the two men considered

\footnotetext{
${ }^{24}$ Chaim Ozer Grodzenski (1863-1940) was one of the dominant decisors and spiritual authorities of his generation. He moved to Vilna in 1883 and was recognized as the city's eminent rabbinical authority two years later. After the death of Rabbi Isaac Elhanan Spector in 1896, he was recognized as the undisputed rabbinical leader of European Jewry.

${ }^{25}$ Isaac Meir Levin (1893-1971), son-in-law of the Gerer Rebbe, was the preeminent political leader of Agudat Yisrael in interwar Poland. He immigrated to Palestine in 1940, where he became the head of the local Agudah branch.

${ }^{26}$ Jacob Rosenheim to Zalman Shragai, May 22, 1938, in ibid., MO140. With "my own friends," Rosenheim was probably referring to Isaac Breuer, a great proponent of cooperation between the two sides and an important leader of PAY.

${ }^{27}$ The two major opponents of any cooperation with religious Zionists were the influential Gerer Rebbe, Rabbi Abraham Mordechai Alter, and the spiritual authority of the Old Yishuv in Jerusalem, Rabbi Joseph Zvi Dushinski. Although they were in the minority, these two rabbis were weighty authorities, who could simply not be outvoted. Jacob Rosenheim's letter to Meir Berlin on these developments is reprinted in Din ve-Heshbon ha-Merkaz ha-Olami shel ha-Mizrahi le-Ve 'idah ha-Olamit ha-15' be-Genevah, 6.8.-13.8.1939, 75 in ARRZ 00636.

${ }^{28}$ Shlomo Zalman Shragai (1899-1995) was one of the central leaders of the religious Zionist workers' movement, Ha-Poel Ha-Mizrachi. Shlomo Ehrman (1885-1965) was a member of international Agudah's leadership from the time of the organization's establishment in 1912. Together with Yitzhak Breuer, he founded his movement's Palestine office in 1918.
} 
forms of cooperation that could "be arranged without more ado, and without the final ratification of our Paris agreements," such as supporting emigrants from Nazi Germany. Shragai and Ehrmann suggested limiting joint activities to Western Europe and the US, thus excluding the very centers of the movements' political struggle-Poland and Palestine. ${ }^{29}$

While the efforts of these two men produced no actual results, others were more successful. In January 1939, Moses Blau, the eminent Agudah leader from the traditionalist settlement in Jerusalem, advanced the idea of a joint fundraising campaign in England and other Western European countries. ${ }^{30}$ Like Ehrmann and Shragai, Blau hoped to avoid contention by focusing on countries in which the ideological struggle between the two Orthodox movements was less intense. He suggested dividing the collected funds evenly, so that each side could distribute its shares independently. During a visit to London, Blau presented his proposal to Meir Berlin, and both parties considered the idea. ${ }^{31}$ In a reversal of prior positions, Blau's suggestion met with consent among Agudah leaders, while most religious Zionists were opposed. Ultimately, Mizrachi's executive in Jerusalem rejected the proposal. Disappointed, Blau threatened to run the fundraising campaign without the involvement of religious Zionists. At this point, Berlin asserted his prestige and power as the central leader of Mizrachi, and signed the London accords together with Jacob Rosenheim-despite a formal rejection from his colleagues in Jerusalem. ${ }^{32}$

In the accords, signed on February 21, 1939, the two sides agreed to launch joint fundraising campaigns in several Western European countries. The resulting revenues were to be divided equally, and transferred to the parties' respective Palestine funds-Mizrachi's Keren Erez Yisrael and Agudat Yisrael's Keren Ha-Yishuv. The two groups would fundraise in England, Holland, France, Belgium, and Switzerland "with the consent of local territorial organizations." Neither of the two sides was to fundraise independently for its institutions in Palestine until the campaign, scheduled for the end of the Jewish year 5698 in September 1939, came to a close. ${ }^{33}$

Leaders of Agudah and Mizrachi met in London on March 8 to kick off the campaign. Representatives of their world movements, as well as members

\footnotetext{
${ }^{29}$ Solomon Ehrmann to Meir Berlin and Jacob Rosenheim, November 30, 1938, in ARZ MO155.

${ }^{30}$ Moses Uri Blau (1885-1946) was born in the traditionalist settlements in Jerusalem. He came to represent the conservative circles of the Old Yishuv, edited the local Agudah's mouthpiece Kol Yisrael, and became one of the movement's preeminent leaders.

${ }^{31}$ Jacob Rosenheim to Meir Berlin, January 22, 1939, in ibid., MO151.

${ }^{32}$ See Bauer, Ha-Yahasim ha-Penimiim, 96.

${ }^{33}$ Agreement between the Agudat Yisrael World Organization and the Mizrachi World Organization, February 21, 1939, cited in its English translation in ARZ MO155.
} 
of their English branches, arranged the details for joint fundraising in England, where the campaign got off to a good start. In other countries, however, the picture did not look as bright. Only a few days after the meeting in London, Agudah branches in Switzerland, Holland, and Belgium announced their refusal to fundraise with their Mizrachi colleagues. Despite these setbacks, Rosenheim and Blau were determined to carry through the agreement, at least in England. Yet in London, too, the situation soon deteriorated. The nomination of treasurers elicited struggles, as English Mizrachists were unwilling to accept the Agudah candidate for treasurer-the movement's British leader, Harry Goodman. ${ }^{34}$ Tense letter exchanges between Rosenheim and Berlin followed, but despite several attempts by the former to resolve the situation, they were unable to reach compromise. Finally, during the last days of June 1939, Rosenheim informed Berlin that Agudah's Council of Torah Sages had voted against ratifying the Paris agreements. In response, Mizrachi representatives canceled the joint fundraising arrangements. The efforts of the two Orthodox movements to join forces had reached a dead end. ${ }^{35}$

\section{The Dynamics of Political Competition}

The negotiations between Mizrachi and Agudah leaders in Paris and London raise a number of questions regarding the political dynamics involved. What precipitated these meetings between high-ranking representatives of both movements after decades of animosity devoid of similar encounters? Many of the calls for cooperation and mutual rapprochement during 1938 and 1939 highlighted the urgency of easing the economic and religious plight of the Jewish masses. But the dire situation of Jews in Europe and Palestine during the late 1930s is not enough to explain the timing of the negotiations. The unprecedented destruction and ineffable suffering that the Jews of Europe and Palestine experienced during World War I had not generated comparable attempts at cooperation. ${ }^{36}$ What is more, among Agudah and Mizrachi in

\footnotetext{
${ }^{34}$ Harry Aron Goodman (1899-1961) was a British businessman and Agudah leader from London. Inter alia, he edited the British party's Jewish Weekly and was the president of Adath Yisroel Congregation.

${ }^{35}$ Much of the correspondence between Rosenheim and Berlin can be found in ARZ MO 155. This file also contains the Summary of Correspondence and Relevant Documents in connection with the proposed Mizrahi-Agudah Agreement, Mizrahi Federation of Gt. Britain and Ireland, July 1939. Regarding the rabbinic council's rejection of the proposal, see Jacob Rosenheim to Meir Berlin, May 28, 1939, in ibid., MO 155. For a report about Mizrachi's cancellation of the London treaty, see Betzalel Bidziński to Mizrachi Swiss, June 13, 1937, in ibid., MO161. ${ }^{36}$ While individual leaders had met in the aftermath of the war, their discussions had not reached a similar intensity, nor did they achieve any tangible results. For a depiction of
} 
Poland and Palestine - the areas most urgently in need of help-were some of the strongest opponents of cooperation. The London agreements, as we have seen, aimed specifically to exclude these branches from any active involvement in cooperative endeavors.

To gain better understanding of why Mizrachi and Agudah leaders were willing to enter into negotiations during these years, we must consider their mutual dynamics and questions of ideological and organizational development. Political competition was indeed harsh and often relentless, in particular in Poland and Palestine. In the Second Polish Republic, representatives of the two movements competed within the same communal structures (kehillot) and fought directly for power and influence, as well as for jobs for their adherents. In Palestine, such forms of competition were less pronounced, as Agudah had its strongholds in the traditionalist communities of the Old Yishuv, and Mizrachi dominated religious councils in the Zionist New Yishuv. Nevertheless, the Old and New yishuvim were not completely separate spheres, and during the 1920s and 1930s they became increasingly intertwined. Furthermore, as the public sector developed under the British Mandate and emerging Zionist institutions fulfilled many of the functions of a modern state, the question of relations between religion and state gained urgency.

Religious life and institutions in Palestine deteriorated over the course of the 1930s due to the steady influx of largely secular immigrants. ${ }^{37}$ When the British began to consider the partition of Palestine to stabilize the increasingly tense and violent situation that followed the Arab revolt of 1936, Orthodox leaders were on high alert. They fiercely debated appropriate responses to unfolding events, as well as the outlook and constitution of a future Jewish state. The role of Judaism in what would clearly be a largely secular state was a major concern of Orthodox representatives across the spectrum. ${ }^{38}$ All sides agreed on the need to safeguard basic Orthodox institutions and frameworks vis-à-vis the secular authorities of such a state, but that is where their agreement ended. The two movements promoted distinct and often contradictory

Mizrachi-Agudah relations during these years, see Yosef Elihai, "Ha-Imut bein 'ha-Mizrahi' le-vein Agudat Yisra'el be-Polin be-Shanim 1917-1920," Sefer Shragai. Perakim be-Heker ha-Ziyonut ha-Datit ve-ha- 'Aliyah le-'Erez. Yisra'el, ed. Mordekhai Eli' av and Yitzhak Rafa'el (Jerusalem, 1981), 96-117.

${ }^{37}$ For example, complaints from all the Jewish settlements in Palestine to central Mizrachi leaders in Jerusalem about the public violation of the Sabbath increased significantly during the second half of the 1930s. For a selection of such letters, see CZA S51/193.

${ }^{38}$ Despite their general opposition to a Jewish state, in the late 1930s Agudah leaders even drafted their own version of a constitution in the hope of securing Orthodox rights. The draft proposals by Moses Blau and Yitzhak Breuer were republished in Isaac Lewin, Material for the Preparation of a Constitution for the Jewish State: On a Religious Basis [in Hebrew] (New York, 1948). 
approaches to the role of religion in a future state, and rivalries within the tripartite structure of the $\mathrm{ZO}$ turned their representatives into bitter adversaries. ${ }^{39}$

In the first decades of their existence, both movements were preoccupied with the consolidation of their respective organizations. From the founding of Agudat Yisrael in 1912 until its first World Congress in 1923, ideological and organizational boundaries were largely in flux. Both sides struggled to define their own essence as well as mutual boundaries. Any discussion of cooperation immediately raised hopes, on both sides, that one movement might succeed in drawing the other closer, and a merger seemed a realistic option, at least to some. This changed in the early 1920s, as Agudists consolidated their movement's organizational outlook and political alignment. In the period thereafter, communication between the organizations consisted mainly of mutual attacks and polemics in the press. During the 1930s, in response to the deteriorating situations in Europe and Palestine, leaders of both groups reconsidered the possibility of cooperation. Yet these contacts were already of very different character than the negotiations of earlier decades. By this point, both movements had refined their approaches and were organizationally defined, and it had become increasingly clear to leaders of both groups that neither would be able to gain political hegemony over all segments of Jewish Orthodoxy. When Mizrachi and Agudah leaders met in Paris and London, no one expressed serious hopes for a merger. At the meeting in the Ambassador Hotel, Polish Mizrachi leader Samuel Brodt openly addressed the irreconcilable positions of the two movements, and urged both sides to work together lest they tear each other apart. ${ }^{40}$ Above all else, it was the clear differentiation of the two Orthodox movements that allowed the leaders of Agudah and Mizrachi to reconsider political cooperation in the spring of 1938. At the same time, both sides continued to display deep ambivalence about such endeavors, and carefully weighed the political risks and gains of every move.

\section{Yeshiva Funding and the Differing Positions vis-à-vis the Paris Accords}

Among the various avenues of cooperation that Agudah and Mizrachi leaders explored at their meeting in Paris, one of the most urgent and, at the

\footnotetext{
${ }^{39}$ In fact, neither the Mizrachi nor Agudah leaderships were true to their declared commitment that they would not appear separately at discussions with the $\mathrm{ZO}$ or at hearings before the British authorities, even before it became clear that Agudah's rabbinic council would not ratify the agreement. For further details, see Mahla, "No Trinity."

${ }^{40}$ Protokol mi-ha-Yeshivah ha-Meshutefet bein ha-Agudah ve-ha-Mizrahi be-Yom 4.4.1938 be-Malon Ambasador be-Paris, in ibid., 001-495.
} 
same time, most sensitive was improving the economic situation of yeshivot in East Central Europe. These institutions were novel frameworks developed during the nineteenth century. In contrast to earlier yeshivot, they were independent of local communities and drew students from all over Europe. The heads of these prestigious institutions were charismatic leaders, often acknowledged as central religious authorities within the wider Jewish world. ${ }^{41}$ As these yeshivot were training the future religious elite, both Agudists and Mizrachists attached great importance to the issue. The debates following the meeting in Paris highlighted many of the central contentions between the two movements, thereby shedding more light on the overall dynamics of the negotiations.

All the participants at the meeting in Paris agreed that the yeshivot were in dire need of financial support. Mizrachi representatives urged attendees to act immediately and undertake concerted fundraising efforts. Jacob Rosenheim and Moses Blau were reluctant, however, and insisted that no decision be taken without consulting the yeshiva deans. Rosenheim called into question whether the deans would agree to take part in such an endeavor, as they generally resisted any dependence on political parties. Blau warned against publishing any resolution on the topic before consulting the deans themselves. But Meir Berlin brushed aside such concerns and argued that Mizrachi and Agudah should enter a federation for the advancement of Torah studies regardless of the attitude of the deans. Support for such endeavors, he claimed, might be rejected by the administration of the yeshivot, "but the religious masses have both the will and the faith in this possibility." 42

As Agudah politicians cautioned, the Eastern European yeshiva deans were indeed wary of any interference in their institutions. Nonetheless, their attitude towards the two movements differed substantially. Some were themselves members of Agudah's rabbinic council, and others were sympathetic to the movement's activities. Most, however, were deeply opposed to Mizrachi. Even Chaim Ozer Grodzenski, who widely advocated for a general agreement with religious Zionists, strictly resisted cooperation on this plane. ${ }^{43}$ With his colleague Israel Meir Kagan (better known by his pen name Chafetz Chaim), Grodzenski had founded a Yeshiva Council (Va'ad

\footnotetext{
${ }^{41}$ See, inter alia, Immanuel Etkes, ed., Yeshivot u-vate midrashot (Jerusalem, 2006); Shaul Stampfer, Lithuanian Yeshivas of the Nineteenth Century: Creating a Tradition of Learning (Oxford, 2012). On the financial straits of the yeshivot in the interwar period and various stratagems to deal with them, see Ben-Tsiyon Klibansky, The Golden Age of the Lithuanian Yeshivot in Eastern Europe [in Hebrew] (Jerusalem, 2014), 214-88.

${ }^{42}$ Protokol mi-ha-Yeshivah ha-Meshutefet bein ha-Agudah ve-ha-Mizrahi be-Yom 4.4.1938 be-Malon Ambasador be-Paris, in ARRZ 001-495.

${ }^{43}$ See his letter to the Agudah Executive from 1938, in Iggerot R' Hayim Ozer, Kovez Iggerotav shel Maran Rashkahbah, vol. 2 (Bnei Brak, 1999), 349f.
} 
Ha-Yeshivot) in 1924 in order to preserve Eastern European institutions, thus his resistance to joint fundraising highlights the sensitive nature of this issue. ${ }^{44}$ The fact that these institutions were independent of communal structures endowed their deans with great authority and power. Agudists embraced the elevated status of the religious elite, while Mizrachists strongly objected to such trends. By stressing the concept of the "will of the masses," Berlin indirectly challenged the deans' authority, reflecting his movement's broader approach to such matters.

The deans' concerns certainly had some substance. A widely publicized and celebrated agreement between two parties did, indeed, run the risk of exacerbating tensions between the organizations regarding their use of funds and thereby subjecting the yeshivot to unwelcome public and political scrutiny. Mizrachi and Agudah advocated substantially different educational approaches, in particular regarding Zionism and the study of secular knowledge, ${ }^{45}$ leading even well-meaning Mizrachists to admit in private correspondence that the gaps between their movements on matters of education were too wide to allow them to work together productively in the pedagogical realm. ${ }^{46}$ Exacerbating such differences, both sides had for years used their party presses to harshly attack one another's educational facilities. In 1927, the Polish Agudah newspaper Der Yud derided Mizrachi's prominent rabbinic seminary in Warsaw, Takhkemoni, as a factory that produced "boorish" leaders on assembly lines, devoid of any yiddishkayt. ${ }^{47}$ A few years later, the Mizrachi press questioned whether Agudah's flagship yeshiva in Lublin had any value beside the grandiosity of its building. ${ }^{48}$

Mizrachists understood the deans' resistance to joint fundraising as a rejection of their movement, as many of the deans had taken part in Agudah's congress in Marienbad the year before. Such suspicions are hard to dismiss completely. The Vilna region was one of the hotspots of conflict and political tension between the two parties. As the spiritual center of Eastern European Jews, the "Jerusalem of Lithuania," the choice of venue was highly symbolic. Only a few years earlier, the city had been embroiled in a bitter struggle over

\footnotetext{
${ }^{44}$ The organization supported a network of 70 institutions. Much of its organizational work is documented in YIVO Archives; Records of the Va'ad Ha-Yeshivot (Vilna, Poland); RG 25. On the founding of the Yeshiva Council, see Klibansky, Golden Age of the Lithuanian Yeshivot, 214-45.

${ }^{45}$ Many of the important yeshiva heads shared Agudah's reservations regarding secular studies, and leaned toward the non-Zionist, traditionalist party in other matters as well.

${ }^{46}$ See, for example, the letter of the Mizrachist and rabbi from Fulda, Dr. L. Cahn, to the noted Zionist leader Henrietta Szold, June 25, 1937, in CZA S75/342.

${ }^{47}$ Der Yud, December 22, 1927, 2.

${ }^{48}$ Di Yudishe Shtime, February 21, 1935, 3.
} 
its rabbinate. Rabbi Isaac Rubinstein, an important Mizrachi leader, had offended some of the greatest spiritual authorities worldwide by taking the title Chief Rabbi, thus leaving highly accomplished scholars like Chaim Ozer Grodzenski with mere "adjunct" positions (podrabiny). The conflict had been formally settled by the time Mizrachi and Agudah representatives proposed a meeting of rashei yeshivah in the city, with Rubinstein embracing the representative and administrational aspects of his position, and Grodzenski as the accepted spiritual authority. Nevertheless, tensions between the two sides continued to simmer. ${ }^{49}$

As it turned out, a few weeks later Polish Mizrachists also condemned the resolution. Religious Zionist leaders from Poland fiercely reproached their colleagues for having decided on what they considered to be internal Polish affairs without consulting them. Isaac Rubinstein, backed by his colleague Rabbi Isaac Nissenbaum, declared that the Polish Mizrachi would not participate in the conference if it took place in Vilna. Anxious about his own position if an assembly of the great Eastern European rabbinic authorities were to meet in Vilna, he demanded that the event be relocated to Jerusalem. ${ }^{50}$ As noted previously, when Mizrachi and Agudah leaders tried to revive the possibility of cooperation in the months following the collapse of the Paris accords, they dropped the issue of joint activity on behalf of the Eastern European yeshivot.

Despite the qualms of Rosenheim and Blau, the two sides eventually agreed to organize a conference of the yeshiva deans in Vilna, ${ }^{51}$ but the deans, as Rosenheim had predicted, rejected it, expressing concerns about the political independence of their institutions. The protocols of the Paris convention do not record every detail of the discussions, and it is hard to reconstruct exactly how the delegates came to this resolution. Considering the doubts and concerns raised during the meeting itself and the tensions that the issue brought to the surface, it is questionable just how seriously the participants anticipated its ratification. Despite Rubinstein's refusal to hold the meeting in Vilna, it is clear that religious Zionists stood to gain considerably on the political plane. Had the yeshiva deans accepted financial support, they could hardly have continued to "preach hatred against Mizrachi," 52 as some in the

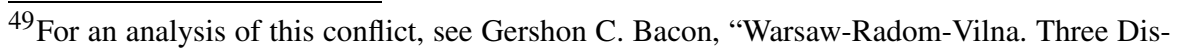
putes over Rabbinical Posts in Interwar Poland and Their Implications for the Change in Jewish Public Discourse," Jewish History 13, no. 1(1999): 103-26.

${ }^{50}$ Isaac Nissenbaum to Mizrachi Executive, May 15, 1938, in ARZ MO147. See also Isaac Nissenbaum to Zeev Gold, June 28, 1938, in ARZ MO162.

${ }^{51}$ Protokol mi-ha-Yeshivah ha-Meshutefet bein ha-Agudah ve-ha-Mizrachi be-Yom 4.4.1938 be-Malon Ambasador be-Paris, in ARRZ-495.

${ }^{52}$ As Nissenbaum claimed in his letter to the Mizrachi Executive, see Isaac Nissenbaum to Mizrachi Executive, May 15, 1938, in ibid., MO147.
} 
movement insinuated, they were wont to do. Agudah, on the other hand, did not anticipate similar benefits from such an agreement. While the organization's leaders, who constantly lamented their lack of financial means, might have gained from Mizrachi's expertise in fundraising, they were reluctant to afford Mizrachi political recognition by some of the outstanding spiritual leaders of the time.

The reason Rosenheim and Blau eventually agreed to include the issue in the Paris accords is likely connected to abiding concerns about the public reputations of the two movements. By the late 1930s, Orthodox leaders sensed that the Jewish masses expected them to overcome their ideological quarrels and join forces to address the dire political and economic situation of European Jewry. In the political framework of the Second Polish Republic, in particular, where both Agudah and Mizrachi competed with other parties for votes and support, such concerns could not be taken lightly. This awareness, in fact, governed much of the politics surrounding the Paris and London accords, as the episodes recounted below will demonstrate.

\section{The Jewish Street and Its Impact on the Negotiations}

Several months after the first contact between Meir Berlin and Jacob Rosenheim regarding a meeting of the two movements, the Agudah executive came together in Vienna. According to the protocols produced from this gathering in January 1938, concerns about Palestine took center stage. In Vienna, Polish Agudah leader Isaac Meir Levin admitted that the movement had done too little for the Jewish settlements in Palestine and urged his colleagues to increase their efforts. "Providence (hashgoho)," he held, "literally chases us with whiplashes to the Land of Israel. The Jewish People is in great danger. The only salvation," he concluded, "is Agudat Yisrael." Notwithstanding this appeal, as soon as the debate turned to Mizrachi's request for a meeting, Levin expressed skepticism. When Rosenheim reported on his exchange with Berlin, Levin immediately questioned the Mizrachi leader's sincerity and suggested that Agudah's rival was not genuinely interested in cooperation. Religious Zionists, in Levin's view, merely wanted to draw political profit from the negotiations. ${ }^{53}$

Levin's accusations reflected heightened political tensions not only in Poland and Palestine, but also in the United States. Agudah had been struggling for years to gain a foothold in the growing Orthodox community over-

\footnotetext{
${ }^{53}$ Protokoll der Sitzung des Wa'ad Ha-Poel der Agudas Jisrael in Wien vom 12.-16. Januar 1938 unter dem Vorsitz des Herrn Präsidenten Jacob Rosenheim, in Archives of Agudath Yisrael of America (following: AAYA) BB47.
} 
seas. Mizrachists, who had already established themselves in AmericanJewish politics, attempted to thwart their plans. American Mizrachi consequently published as a pamphlet a speech delivered by the rabbi of Kovno, Abraham Dober Kahana-Shapira, ${ }^{54}$ at a local Mizrachi conference in the early 1920s, showcasing his attempts to arbitrate between the two parties in the immediate postwar years. Kahana-Shapira had highlighted the willingness of Mizrachists to approach the other side and blamed Agudists for blocking any such attempt. The pamphlet-entitled, "Who is guilty of the schism between Mizrahi and Agudat Yisrael?-was apparently distributed with the intention of maligning Agudah by accusing its leaders of stubbornly rejecting any rapprochement between the two sides. ${ }^{55}$ Against this backdrop, Levin suspected Berlin's inquiry of serving similar purposes. Rabbi Aharon Kotler, dean of the Yeshiva of Slutsk, also attended the Agudah conference in Vienna and voiced suspicions similar to Levin's concerning Mizrachi's intentions. In contrast to Levin, however, Kotler concluded that Agudah could not dare reject Berlin's offer to negotiate, as such a move would severely impact the movement's nascent branch in the United States.

Even Rosenheim himself, who generally advocated rapprochement, at least vis-à-vis his Mizrachi counterparts, was pessimistic. All of the great spiritual authorities, with the exception of Chaim Ozer Grodzenski, he maintained, objected to cooperation. In particular, the notably anti-Zionist Elchonon Wassermann, head of the famous Novardok Yeshiva, had voiced fierce resistance to the two organizations working together for the benefit of educational institutions. ${ }^{56}$ In his conclusion, Rosenheim noted that if negotiations were held, they should focus mainly on the question of a Jewish state, and touch upon other issues only in passing. "But I do not believe," Rosenheim concluded, "that they will lead to any tangible results." According to

\footnotetext{
${ }^{54}$ Rabbi Abraham Dober Kahane-Shapira (1870-1943) was a widely acknowledged spiritual authority. Born in the city of Kobryn, he became the chief rabbi of Kovno in 1923, and later the last chief rabbi of Lithuania before World War II. The Lithuanian Rabbinate was known to be a strong supporter of Mizrachi-Agudah rapprochement.

${ }^{55}$ Abraham Dober Kahane-Shapira, Ver iz shuldig in dem perud tsvishn Mizrahi un Agudat Yisrael? (New York, 1938). The booklet's very publication attests to the heightened significance of Agudah in the US. In 1929, Mizrachi did not even bother to mention its opponent in a similar pamphlet about the movement's purpose and goals (in stark contrast to Mizrachi propaganda literature from Europe during the same period that regularly highlighted the differences between the two parties). See Yehuda Leib Maimon, Vos iz der Mizrahi? (New York, 1929).

${ }^{56}$ Grodzenski's resistance to cooperation on behalf of the yeshivot was already known to both Agudists and Mizrachists by this point. He had expressed his position clearly in a letter to Meir Berlin, as one of the discussants at the Agudah convention pointed out. See Protokoll der Sitzung des Wa'ad Ha-Poel der Agudas Jisrael in Wien vom 12.-16. Januar 1938 unter dem Vorsitz des Herrn Präsidenten Jacob Rosenheim, in AAYA BB47.
} 
the protocols of Agudah's conference in Vienna, not a single voice came out in clear favor of the negotiations. ${ }^{57}$ Much of the rationale behind the Agudah decision to enter such negotiations, as the meeting in Vienna illustrates, was influenced by considerations of the party's public image.

Agudists were not the only ones worried about their reputation. While Agudah leaders were concerned about appearing passive and resistant to rapprochement, their Mizrachi counterparts were anxious to be taken seriously as political equals. This may explain why Berlin seemed surprisingly hesitant in his initial correspondence with Levin and Rosenheim, especially considering that Mizrachists were the ones pushing for cooperation. Once Agudah leaders had agreed to meet, Berlin turned down several suggested venues, among them a proposition to meet in Vienna following a scheduled Agudah assembly. A joint conference, Berlin insisted, should not be merely appended to a convention of one of the parties. Both sides, he demanded, should prove their sincerity by putting in extra effort to meet. ${ }^{58}$ Berlin's sensitivity on this issue demonstrates the extent to which Mizrachists were anxious not to appear to be currying favor with Agudah. Similarly, when the latter's Council of Torah Sages subsequently delayed the ratification of the Paris agreements, some Mizrachists concluded that they had done their bit and should resist any further negotiations because "the Jewish world would consider this to be a flattery of Agudah." 59

At the same time, Mizrachists attempted to take advantage of Agudist concerns about their own public image. When, in May 1938, Rosenheim informed Zalman Shragai that he doubted whether Agudah's rabbinic council would ratify the agreement, the latter asked the Mizrachi executive to seize the moment. "I have the feeling that they want to duck out of the cooperation," Shragai wrote to Berlin, "but there is a lot of pressure from the masses and I think that we should raise this pressure by publishing articles in the press and by postulating the unity of religious Jewry." ${ }^{\circ 0}$ Shragai's comments shed light on the response of Mizrachi media to the Paris accords, more generally. As noted above, the Mizrachi media were quick to publish reports

\footnotetext{
${ }^{57}$ Leaders from Palestine shortly thereafter voiced similar suspicions. In April 1938, the Jerusalem office complained about Mizrachists distorting the facts concerning the Paris agreement in their party propaganda. See a letter from the office of Agudat Yisrael in Jerusalem to Jacob Rosenheim, April 24, 1938 in Archives of Agudat Yisrael in Palestine, Jerusalem, 122. ${ }^{58}$ Berlin also turned down a proposal to meet in Warsaw. See Din ve-Heshbon ha-Merkaz ha-'Olami shel ha-Mizrahi le-Ve'idah ha-Olamit ha-15' be-Genevah, 6.8.-13.8.1939, 63f in ARRZ 006-36.

${ }^{59}$ Elimelech Neufeld to Meir Berlin, May 31, 1938, in ARZ MO140.

${ }^{60}$ Jacob Rosenheim to Zalman Shragai, May 2, 1938; Zalman Shragai to Meir Berlin, May 18, 1938, in ibid., MO143.
} 
of the Paris accords, hailing the agreements as a great victory for Orthodox Jewry in general, and for their party in particular. Just one day after the Mizrachi presidium ratified the Paris agreement, the Mizrachi newspaper from Palestine, Ha-Tsofeh, reported the news on its front page. ${ }^{61}$ Such coverage increased pressure on Agudah by raising hopes among the Jewish masses, who were already inclined to favor cooperation between the parties. What is more, they signaled to readers that religious Zionists-as compared with their traditionalist counterparts-were making every effort to improve the grave situation of religious Jews. ${ }^{62}$

\section{The London Agreements and the Collapse of the Negotiations}

Although Mizrachists had pushed for ratification of the Paris agreements, they were far less enthusiastic about the London accords. With some Agudah leaders pressing for implementation and Mizrachists navigating hesitantly, their roles now seemed almost reversed. In this respect, the London agreements can serve to illustrate the fact that, rather than altruistically working to overcome the schism in Jewish Orthodoxy, both sides carefully weighed the chances and risks of their political cooperation.

As mentioned previously, Berlin ultimately signed the London accords despite his colleagues' resistance. Much political maneuvering followed, but after all the back and forth it seemed that their efforts to mobilize local chapters would finally bear fruit, at least in England. In their joint fundraising endeavors there, two treasurers were to be appointed, one for each side. English Mizrachists nominated their treasurer but did not consent to Agudah's choice. In the resulting letter exchange with Berlin, Rosenheim tried to foster a compromise that would allow the two sides to move forward with the joint campaign. Since the English Mizrachi was not willing to accept Agudah's choice, he suggested nominating one treasurer instead of two, someone independent and impartial, unaffiliated with either party. ${ }^{63}$ The English Mizrachi, however, insisted that Agudat Yisrael must nominate an alternate candidate and referred to a "gentleman's agreement," that Berlin and Rosenheim had

\footnotetext{
${ }^{61}$ Ha-Zofeh, April 21, 1938, 1.

${ }^{62}$ Agudists too were concerned about strengthening support for their movement. Yet, at the same time, they were wary of modern mass politics. Moreover, comments in the press were bound to ignite criticism from conservative circles and raise the suspicions of the spiritual leadership against any cooperation with the Zionists. In the Old Yishuv, indeed, the news of an agreement with Mizrachi sparked fierce disapproval and discussion. See Agudat Yisrael in Jerusalem to Jacob Rosenheim April 24, 1938, in Archives of Agudat Yisrael in Palestine, Jerusalem 122.

${ }^{63}$ Jacob Rosenheim to Mizrachi Federation, March 24, 1939 in ARZ MO112-24.
} 
allegedly made about this. When Rosenheim contacted Berlin, he expressed suspicion that English Mizrachists were not actually interested in implementing the London accords. Berlin dismissed this and reproached his correspondent for not keeping to their agreement. Returning the blame, he complained that Agudah, once again, was doing everything to frustrate mutual efforts at cooperation, and he accused the Swiss, Belgian, and Dutch Agudah chapters of violating the accords. This, as Rosenheim rightly pointed out in his answer, was not factually correct, as the agreement explicitly stated that each national chapter would agree separately to conduct joint fundraising campaigns. ${ }^{64}$

Berlin, without doubt, knew this. What, then, motivated his uncompromising stance? Among Mizrachi leaders, the London accords had been highly unpopular from the time Moses Blau first raised the idea. Only a small minority saw in these agreements an actual opportunity to bring the two sides closer together. Most Mizrachists decried their limited dimension and suspected that Agudists were merely seeking economic gain. Religious Zionists were well aware of the critical role that fundraising played in the success of a political movement. Just one year earlier, in January 1938, they themselves had made concerted efforts to professionalize their own fundraising in Poland and set up a board devoted exclusively to dealing with such matters. Mizrachi leader Elimelech Neufeld had come to Poland from Palestine to advertise these efforts, and recruit activists and rabbis for practical help and support. Zeev Gold, in a communication with the Polish leader Isaac Nissenbaum about these efforts, stressed the immense importance of Mizrachi's Palestine fund, Keren Erez Yisrael, and called on his Polish colleagues to turn the Jewish festival of Shavuot (Feast of Weeks) into a fixed date for raising money specifically for this fund. The festival during which Jews celebrated God's giving of the Torah to Israel, he pointed out, was the ideal occasion for such activities. Shavuot was the only holiday, he added, on which the Jewish National Fund did "not yet have a monopoly." The ZO, he stressed, owed its strength to its successful fundraising. ${ }^{65}$ In such matters, Mizrachists had a clear advantage over their Agudist opponents due to their tighter organization, their unequivocal embrace of social and political activism, and their affiliation with the Zionist movement.

In the early winter of 1939, Meir Berlin was in regular contact with the Polish Mizrachi leader Simha Bunam Feldman. Reporting to Berlin on the situation in Poland, Feldman painted a depressing picture of the local branch, excoriating virtually every one of the eminent local Mizrachi leaders. But even in this bleakest of assessments, Mizrachi still fared far better than its non-Zionist counterpart. Feldman interpreted Blau's suggestion for

\footnotetext{
${ }^{64}$ Summary of Correspondence and Relevant Documents, in ibid., MO155.

${ }^{65}$ Zeev Gold to Isaac Nissenbaum, January 2, 1938, in ibid., MO147.
} 
joint fundraising as a sign of Agudah's weakness. Yitzhak Breuer's efforts to collect money for the Keren Ha-Yishuv had been unsuccessful. Blau's suggestion, Feldman believed, was simply an attempt to improve the situation of Agudah, to learn from Mizrachists, and to gain from their connections and networks. ${ }^{66}$ Religious Zionists should not allow this to happen, he asserted, as a joint campaign would also expose Mizrachi's shortcomings to Agudists. "Why," Feldman concluded, "would we reveal to them that we, too, have an Achilles' heel?"67

Throughout the spring of 1939, opposition within Mizrachi to an agreement on joint fundraising efforts continued to mount. In particular, Mizrachists from Switzerland and England expressed their opposition to such frameworks, confirming Rosenheim's suspicions. A few days before Berlin cancelled the deal, he received an angry letter from Zurich, in which Swiss Mizrachi leaders expressed their complete rejection of any cooperation with the local Agudah branch and dismissed out of hand any positive aspects of the agreement. "We cannot conceal," the enraged Swiss leaders concluded, "that this affair has shaken our confidence in the Mizrachi executive." ${ }^{68}$ British leaders made similarly disparaging comments regarding local cooperation. Their branch, they reported to Berlin, had already begun collecting funds for the Palestine endeavors of their movement, and they were not willing to share this money with a political opponent. "Actually," they told Berlin forthrightly, "at the meeting [we held last April] every member was in favour of seeking a method by which we could conveniently get out of the agreement." 69 They found their "convenient method" in the quarrel over the appointment of an Agudah treasurer. Nevertheless, in August 1939, in its official report on the negotiations, Mizrachi singled out their political opponents as solely responsible for the agreement's failure. "We thus see that not even Agudah's rabbinic council decides, but John Doe. We have made every effort - and maybe even more-in order to reach unity. If this, to our deepest regret, did not materialize, the blame is definitely not on our side." 70

\footnotetext{
${ }^{66}$ In this context it is worth pointing out that personal motives might also have guided Moses Blau. He was a bitter rival of Isaac Breuer and may have seen the fundraiser as opportunity to challenge Breuer's authority. This led to bitter conflict between the two men, which could only be settled through strong pressure from their party colleagues. See Protokoll der Sitzung des Wa'ad Ha-Poel der Agudas Jisrael, in AAYA BB47.

${ }^{67}$ Simha Feldman to Meir Berlin, January 30 to March 1, 1939, in ibid., MO151.

${ }^{68}$ Mizrachi Swiss to Mizrachi Executive Jerusalem, May 26, 1939, Betzalel Bidziński to Mizrachi Swiss, June 13, 1939, in ibid., MO161.

${ }^{69}$ W. Frankel, secretary of British Mizrachi to Berlin, April 25, 1939, in ibid., MO160.

${ }^{70}$ Din ve-Heshbon ha-Merkaz ha-'Olami shel ha-Mizrahi le-Ve 'idah ha-'Olamit ha-15' beGenevah, 6.8.-13.8.1939, 80 in ARRZ 006-36. For an account of the agreements from the Agudist point of view, harshly blaming Mizrachists for their failure, see Kol Yisrael, August 10, 1939, 5f; August 16, 1939, 2, 4.
} 


\section{Conclusions: The Historic Significance of the Two Agreements}

Less than a month after the Mizrachi executive published its final evaluation of their negotiations with the Agudah leadership, the German Wehrmacht invaded Poland. Following the ensuing destruction of European Jewry in the Holocaust, Palestine and the U.S. emerged as the two most important centers of Jewish life and politics. Against this backdrop, it is questionable whether the Paris and London agreements would have been implemented even if they had been ratified. Nevertheless, these failed negotiations offer historians an important window into relations between the two largest and most influential Orthodox movements on the eve of World War II. As this article demonstrates, both sides had their own specific reasons for participating in the talks. Overall, the religious Zionists displayed a greater willingness to cooperate during these years. Yet, as I have argued throughout, Mizrachi's enthusiasm over the Paris accords and the reluctant responses of the Agudists should not lead us to conclude that this is simply another example of Zionist activism versus the alleged passivity of non-Zionist Orthodoxy. Mizrachi's report on the negotiations, which is the main available source for this historic meeting, demonstrates that this narrative played a role in the unfolding of the event itself and dominated Mizrachi discourse in its aftermath, which is reason in itself to treat it with particular caution. A more measured historical approach will carefully analyze the approaches and interactions of the two movements in light of their distinct political interests and concerns. It is critical to keep in mind that Mizrachists and Agudists were not solely driven by ideology but were locked in competition for power and leadership within the camp of traditionalist Jewry. These leaders' attempts to cooperate and the public coverage of such endeavors were part and parcel of their political rivalry.

In addition to sincere concern over the fate of Orthodox Jewry, both parties worried about their reputation among the Jewish masses. In light of the grave geopolitical situation, neither wanted to appear closed-minded or unwilling to compromise. These apprehensions helped bring Mizrachists and Agudists to the negotiating table in the first place. Over time, however, the ongoing concern of each side about maintaining its public image increasingly impeded negotiations. At first, religious Zionists pushed more adamantly for an agreement. The final ratification of the Paris accords would have been a major success for their movement, affording them at least symbolic recognition by some of the most widely accepted spiritual authorities of the day. The value of such recognition is hard to overestimate. Indeed, when it came to the London accords, even staunch opponents of cooperation with Agudah expressed willingness to drop their objection if it granted Mizrachi's work 
"rabbinic certification" (hekhsher). ${ }^{71}$ But the London treaty had a limited focus and was confined to Western Europe, and, in actuality, the accords would not have awarded Mizrachi such a hekhsher. Consequently, most Mizrachists concluded that the price they would have to pay in this round was too high and not worthwhile. Since they did not want to appear to be backing out, however, they needed an excuse for dismantling the arrangement. Agudists, on the other hand, were, from the outset, reluctant to work with their opponents on sensitive religious issues, concerned that such cooperation could be read as recognition of Zionist activism and Mizrachi. The London agreement, which limited cooperation to a joint fundraising campaign, would have allowed Agudah to reap significant benefits without paying a meaningful political price, and therefore enjoyed broader support among the party leadership. In many ways, these reactions reflected the power relationship between the two movements. Agudah was in a much stronger position when it came to the support of the traditionalist milieu. However, due to their ambivalence toward social and political activism and their reluctance to engage in modern mass politics, they lacked funding and political partnership. Here, Mizrachists had the advantage. This is what Feldman had in mind when raising suspicions about Agudah gaining important insights and networks through joint fundraising.

Local dynamics played a significant role during negotiations as well. This became blatantly obvious during the implementation of the London agreements, when individual national chapters resisted cooperation. Agudah, in particular, was riven by power struggles between different regional centers, ${ }^{72}$ but such conflicts plagued religious Zionism as well, as became clear when Polish Mizrachists protested elements of the Paris agreements that they took to be an intrusion into their internal affairs. Local sensitivities had, in fact, already been raised as a concern by participants in the meeting at the Ambassador Hotel. While all attendees emphasized the importance of cooperation for the improvement of religious life and institutions in Palestine and worldwide, just where and how such cooperation could be reached had been a highly contentious issue. Some representatives were convinced that the two movements had to start their common efforts in Palestine. Cooperation there, they hoped, would lead to changes in the attitudes of Diaspora leaders as well, and demonstrate the benefits of such endeavors. Others held the opposite to be the case. Only after the countries in the Diaspora set a good example, they claimed, would Jewish leaders in Palestine follow suit. ${ }^{73}$ The

\footnotetext{
${ }^{71}$ See Simcha Feldman's exchange of letters with Meir Berlin, as cited above, Simha Feldman to Meir Berlin January 30, 1939, in ARZ MO151.

${ }^{72}$ For a detailed description of these struggles, see Fund, Perud o Hishtatfut.

${ }^{73}$ Protokol mi-ha-Yeshivah ha-Meshutefet bein ha-Agudah ve-ha-Mizrahi be-Yom 4.4.1938 be-Malon Ambasador be-Paris, in ibid., 001-495.
} 
dividing lines in these debates ran across both camps. Many of those involved expressed general support for cooperation but seemed reluctant when it came to implementation in their own national chapters. Such hesitations were well-founded, as the quarrels over joint fundraising endeavors eventually made clear. The complaints of the local Swiss and British chapters were what sabotaged the London accords only one year later.

The fact that the negotiations in Paris and London, and subsequent debates over the ratification of these agreements were shaped largely by power struggles and political dynamics does not mean that religious and ideological issues played no role. British partition plans, however, confronted Orthodox leaders from across the spectrum with the challenge of safeguarding religious life and institutions in a future state, creating an urgent, common agenda. While ideologically Mizrachists promoted the idea of Jewish statehood, they, like their non-Zionist counterparts, also feared secular domination. As a result, both sides were willing to work together in this area. Indeed, the St. James Conference on the partition of Palestine, held in February 1939, may have been one of the incentives for Mizrachi and Agudah to renew their attempts at cooperation within the framework of the London accords. But any steps beyond this very limited cooperation were highly contentious. When the British failed to foster a compromise between Arabs and Zionists, Orthodox leaders became less inclined to cooperate and this may at least partially explain their eventual abandonment of the agreements. ${ }^{74}$

From a contemporary perspective, it is difficult to understand how Orthodox leaders got so caught up in seemingly petty political calculations and tactical maneuvering on the eve of the Nazi inferno. While the historical actors could not have known the full implications of the threat facing European Jewry, they were well attuned to the dire social and political situation of traditionalist Jewry at the time. The fact that Orthodox leaders were not willing to work together even under these circumstances attests to the depth of the rift between them. Even the drastic and far-reaching geopolitical shifts of these years did not lead to ideological rapprochement between the movements. The essential cultural and religious issues that divided the two groups only intensified and deepened the rifts between them. Beyond their distinct political approaches, the visions of Orthodox society that Agudists and Mizrachists advanced looked increasingly different. The social and cultural institutions that each movement sponsored or supported shaped the lives of Orthodox Jews well beyond the realm of politics, fostering ever more significant socio-cultural separation, and generating two separate and distinct

\footnotetext{
${ }^{74}$ For such a line of argument, see Nathaniel Katzburg, in his introduction to Meir Berlin's autobiography: Meir Bar-Ilan: Me-Volozhin ad Yerushalayim, vol. 1 (Tel Aviv, 1971), 46.
} 
milieus that would emerge more fully during the early years of Israeli statehood: Ultra-Orthodoxy and national-religious Judaism. ${ }^{75}$

It is precisely from this perspective that the negotiations in Paris and London constitute an important stage in the relations of the two movements. Much as some participants feared, negotiations between Mizrachi and Agudah leaders expressed the mutual, if indirect, acknowledgment that both parties legitimately represented segments of Orthodox Jewry. While the substantial differences between the movements were clear to those involved, the negotiations also highlighted issues and concerns common to both camps, thereby laying the foundations for subsequent negotiations and cooperation. Indeed, mutual recognition and the clear demarcation of the two camps ultimately allowed Agudah and Mizrachi leaders to engage in a significant if short-lived formal cooperation one decade later. In November 1948, representatives of all Orthodox parties in the nascent Israeli government formed the "United Religious Front," a temporary electoral alliance that worked to establish and secure religious institutions and frameworks in the recently founded Jewish state. While the electoral alliance itself disintegrated after only a few years, the frameworks that it helped institute deeply influenced Israeli society and state over the following decades and beyond.

Acknowledgments Thank you to Rachel Furst for her critical comments and editing, as well as to the anonymous reviewers of this journal for their insightful suggestions and remarks. The research for this article was generously supported by the Minerva Foundation of the Max Planck Society and the Memorial Foundation for Jewish Culture in New York. It expands on central themes of my forthcoming monograph, Orthodox Judaism and the Politics of Religion: From Prewar Europe to the State of Israel.

Funding Note Open Access funding provided by Projekt DEAL.

Publisher's Note Springer Nature remains neutral with regard to jurisdictional claims in published maps and institutional affiliations.

\footnotetext{
${ }^{75}$ Employing the concept of milieus, historians of Western Europe have investigated the emergence of a thorough net of institutions and frameworks that shaped the everyday lives of workers, Catholics, and other societal groups during the nineteenth and early twentieth centuries. These networks created discrete microcosms that helped to establish and maintain loyalties and identification, and thus shaped interpretative patterns, moral standards, and emotional ties. See, for example, Arbeitskreis für kirchliche Zeitgeschichte (AKKZG) Münster, "Katholiken zwischen Tradition und Moderne. Das katholische Milieu als Forschungsaufgabe," Westfälische Forschungen 43 (1993): 588-654; idem, "Konfession und Cleavages im 19. Jahrhundert. Ein Erklärungsmodell zur regionalen Entstehung des katholischen Milieus in Deutschland," Historisches Jahrbuch 120 (2000): 358-95; Karel Dobbelaere, "Secularization, Pillarization, Religious Involvement, and Religious Change in the Low Countries," in World Catholicism in Transition, ed. Thomas M. Gannon, S.J. (New York, 1988), 80-113.
} 
Open Access This article is licensed under a Creative Commons Attribution 4.0 International License, which permits use, sharing, adaptation, distribution and reproduction in any medium or format, as long as you give appropriate credit to the original author(s) and the source, provide a link to the Creative Commons licence, and indicate if changes were made. The images or other third party material in this article are included in the article's Creative Commons licence, unless indicated otherwise in a credit line to the material. If material is not included in the article's Creative Commons licence and your intended use is not permitted by statutory regulation or exceeds the permitted use, you will need to obtain permission directly from the copyright holder. To view a copy of this licence, visit http://creativecommons.org/licenses/by/4.0/. 